\title{
PENGARUH PENAMBAHAN KACANG MERAH (Phaseolus Vulgaris L.) TERHADAP DAYA TERIMA DAN KANDUNGAN ZAT BESI (Fe) BISKUIT UNTUK WANITA HAMIL
}

\author{
Suci Purnama Qudsy' ${ }^{1}$ Roifah Fajri'2*, Naintina Lisnawati ${ }^{3}$ \\ ${ }^{1,2}$ Sekolah Tinggi Ilmu Kesehatan Holistik \\ ${ }^{3}$ Universitas Diponegoro \\ *Korespondensi: Jl. Veteran No.272 Ciseureuh Purwakarta, Email: roifahf@gmail.com
}

\begin{abstract}
ABSTRAK
Latar Belakang: Prevalensi anemia defisiensi besi (ADB) pada wanita hamil di Indonesia mencapai $37,1 \%$ pada tahun 2013 . Konsumsi makanan tambahan yang mengandung zat besi dapat menjadi alternatif pencegahan ADB pada ibu hamil. Biskuit kacang merah merupakan salah satu makanan tambahan yang mengandung zat besi ( $\mathrm{Fe}$ ) dengan harga terjangkau.

Tujuan Penelitian: Membuat biskuit yang mengandung zat besi ( $\mathrm{Fe}$ ) dan mengetahui pengaruh penambahan kacang merah terhadap daya terima dan kandungan zat besi (Fe) pada biskuit kacang merah.

Metode: Penelitian ini terdiri dari 2 tahap yaitu, pembuatan biskuit kacang merah dan analisis (uji daya terima dan uji kandungan zat besi). Desain penelitian menggunakan Rancangan Acak Lengkap (RAL) 1 faktor dengan 3 perlakuan penambahan kacang merah yang berbeda (20\%, $50 \%$ dan $80 \%$ ).

Hasil: Kacang merah yang diolah menjadi biskuit tidak memiliki pengaruh terhadap daya terima pada parameter aroma $(p=0,539)$ dan rasa $(p=0,237)$, namun memiliki pengaruh terhadap parameter warna $(p=0,028)$. Warna yang paling disukai oleh panelis yaitu pada formulasi A1 dengan perbandingan tepung terigu:tepung kacang merah 80\%:20\% dengan nilai persentase 96,67\% (29 dari 30 orang menyukai sampel). Penambahan kacang merah tidak memiliki pengaruh pada kandungan zat besi (Fe) biskuit $(p=0,368)$.

Simpulan: Penambahan kacang merah tidak berpengaruh terhadap daya terima aroma, rasa dan kandungan zat besi biskuit, namun berpengaruh terhadap warna biskuit.
\end{abstract}

Kata kunci: daya terima, zat besi, biskuit kacang merah

\begin{abstract}
Background: Prevalence of pregnant women with iron deficiency anemia in Indonesia reach $37.1 \%$ in 2013. Consumption of additional food containing iron (Fe) can be prevention alternative for iron deficiency anemia on pregnant women. One of a kind additional food containing iron ( $\mathrm{Fe}$ ) with affordable price is red kidney beans biscuit.

Objective: To developt biscuits containing iron (Fe) and find the effects of red beans addition on the acceptance and the iron (Fe) content of biscuit.

Method: First stage of this study were the production and formulation of red bean biscuits. The second stage was analysis (acceptability test and iron content test) of selected biscuit from first stage. The study design used a Completely Randomize Design (CRD) with 1 factor and 3 treatments of different red beans addition (20\%, 50\% and 80\%).

Results: Red kidney beans addition didn't have an effect on the flavour ( $p=0.539)$ and taste ( $p=0.237)$ parameters of biscuits, but had on the colour parameter $(p=0.028)$. Most preferred biscuits color was sample A1 (wheat flour : red bean flour comparison 80\% : 20\%) with $96.67 \%$ panelist like it (29 out of 30 people). Red kidney beans addition had no effect on the iron ( $\mathrm{Fe}$ ) content of biscuit ( $p=0.368$ ).

Conclusion: The addition of red kidney beans didn't affect on the acceptability, iron content, flavour, and taste parameters, but only had on colour parameter of biscuits.
\end{abstract}

Keywords: Acceptance, iron content, red kidney bean biscuits 


\section{PENDAHULUAN}

Anemia defisiensi besi sangat sering terjadi di dunia termasuk Indonesia. Anemia defisiensi besi dapat terjadi pada semua golongan umur ditandai dengan rendahnya kadar hemoglobin dalam darah. Hasil Riset Kesehatan Dasar (Riskesdas) tahun 2013, menunjukkan persentase anemia pada wanita hamil di Indonesia masih cukup tinggi yaitu sebesar $37,1 \%{ }^{1}$

Anemia pada wanita hamil akan meningkatkan resiko saat masa kehamilan yaitu, kematian saat melahirkan, Berat Badan Lahir Rendah (BBLR), mudahnya terkena penyakit infeksi pada ibu dan janin, meningkatkan risiko keguguran serta melahirkan bayi prematur. ${ }^{2}$ Ada beberapa faktor penyebab terjadinya anemia pada kehamilan yaitu, paritas, umur ibu, status ekonomi dan kepatuhan konsumsi tablet zat besi $(\mathrm{Fe})^{3}$ Berdasarkan hasil Riset Kesehatan Dasar (Riskesdas) tahun 2013, pemberian tablet tambah darah pada wanita hamil di Indonesia sebesar 85\% pada tahun 2012.3 Meskipun pemerintah sudah melakukan pemberian 90 tablet $\mathrm{Fe}$ selama periode kehamilan, namun angka kejadian anemia wanita hamil di Indonesia masih tinggi. ${ }^{2}$ Pemberian tablet $\mathrm{Fe}$ oleh pemerintah masih kurang efektif karena masih banyaknya wanita hamil yang tidak mengkonsumsi tablet tambah darah. Hal itu disebabkan karena efek samping saat mengkonsumsi tablet Fe seperti rasa mual, aroma tidak enak dan pusing yang dikarenakan efek bau logam pada tablet tambah darah ${ }^{4}$

Selain tablet $\mathrm{Fe}$, zat besi juga dapat diperoleh dari sumber makanan hewani dan nabati. Kacang merah merupakan salah satu sumber pangan nabati dengan kandungan zat besi ( $\mathrm{Fe}$ ) non hem yang cukup tinggi. Penyerapan zat besi kacangkacangan 4\%-7\% pada wanita yang kekurangan zat besi, dengan demikian pada 100 gram kacang akan memenuhi kebutuhan zat besi sekitar 30\%-50\%. Konsumsi zat besi secara teratur diharapkan dapat membantu memerangi defisiensi zat besi. ${ }^{5}$ Kacang-kacangan memiliki sumber zat besi hingga $10 \mathrm{mg}$ per 100 gram yang dapat dimanfaatkan sebagai biofortifikasi. ${ }^{5}$ Menurut Badan Pusat Statistik (2011), produksi kacang merah di
Indonesia tergolong cukup tinggi, yaitu mencapai 116.397 ton pada tahun 2010.6 Di Indonesia pengolahan kacang merah masih tergolong rendah, kacang merah biasa dikonsumsi oleh masyarakat dengan cara diolah menjadi sayur, toping es dan isian kue. Kacang merah dalam bentuk segar memiliki masa simpan yang cukup singkat, sehingga dibuatlah tepung kacang merah. Pembuatan tepung kacang merah dipilih karena dapat memudahkan dalam proses inovasi pemberagaman produk pangan, diantaranya yaitu biskuit kacang merah. Pembuatan biskuit dengan penambahan kacang merah dipilih karena biskuit memiliki kadar air tidak lebih dari 5\%, sehingga memiliki daya simpan yang cukup lama. Biskuit merupakan salah satu produk makanan yang digemari oleh seluruh kalangan usia. ${ }^{7}$ Pembuatan biskuit kacang merah pada penelitian ini diharapkan dapat diterima oleh wanita hamil sebagai makanan tambahan.

Menurut Saksono (2012), konsumsi biskuit di Indonesia mengalami peningkatan sebesar 5\%-8\% seiring dengan peningkatan konsumsi domestik. ${ }^{8}$ Sehingga diharapkan pembuatan biskuit dengan penambahan kacang merah pada penelitian ini dapat menjadi alternatif pangan tinggi zat besi (Fe), karena masih rendahnya konsumsi zat besi (Fe) pada wanita hamil.

Tujuan penelitian ini adalah membuat makanan tambahan yang mengandung zat besi (Fe) dan mengetahui pengaruh penambahan kacang merah terhadap daya terima dan zat besi pada biskuit. Perbandingan tepung terigu dengan kacang merah pada penelitian ini mengacu dari beberapa penelitian sebelumnya, yaitu, A1= $80 \%: 20 \%, \quad \mathrm{~A} 2=50 \%: 50 \%$, dan $\mathrm{A} 3=$ 20\%:80\%. Formulasi yang dipilih pada penelitian ini adalah penambahan kacang merah dengan kadar rendah, sedang dan tinggi, untuk mengetahui pengaruh penambahan kacang merah terhadap daya terima dan kandungan zat besi (Fe) pada biskuit untuk wanita hamil.

\section{METODE PENELITIAN}

Rancangan percobaan yang digunakan pada penelitian ini yaitu menggunakan Rancangan Acak Lengkap (RAL), dengan satu faktor yaitu 
perbandingan tepung terigu dan tepung kacang merah dengan 3 kali pengulangan. Perbandingan jumlah tepung terigu dan tepung kacang merah adalah $\mathrm{A} 1=80 \%: 20 \%$, $\mathrm{A} 2=50 \%: 50 \%, \mathrm{~A} 3=20 \%: 80 \%$. Analisis yang dilakukan meliputi uji daya terima dan uji kandungan zat besi ( $\mathrm{Fe}$ ) dengan 3 kali ulangan analisis. Sebagai tambahan peneliti juga akan melakukan uji kadar air. Penelitian menggunakan uji hedonik dengan 6 skala untuk daya terima, uji AAS (Atomic Absorption Spektrofotometry) untuk kandungan zat besi (Fe) dan metode gravimetri untuk uji kadar air. Panelis untuk uji daya terima dalam penelitian ini berjumlah 30 orang wanita hamil di Desa
Citalang Kabupaten Purwakarta. Data yang diperoleh kemudian dianalisis statistik, uji daya terimadan uji kadar air menggunakan analisis ANOVA, sedangkan uji kandungan zat besi (Fe) menggunakan analisis Kruskal Wallis. Pembuatan tepung kacang merah, pembuatan biskuit dan uji daya terima dilakukan di Desa Citalang Rt 02 Rw 01 Kabupaten Purwakarta. Pengujian kandungan zat besi dan kadar air dilakukan di Balai Laboratorium Kesehatan Provinsi Jawa Barat.

\section{HASIL PENELITIAN \\ 1. Daya Terima}

Tabel. 1 Hasil Uji Daya Terima Biskuit Kacang Merah

\begin{tabular}{ccccc}
\hline \multirow{2}{*}{ Kategori } & \multirow{2}{*}{ Skor } & \multicolumn{3}{c}{ Sampel } \\
\cline { 3 - 5 } & & A1 $(\%)$ & A2 $(\%)$ & A3 $(\%)$ \\
\hline \multirow{2}{*}{ Aroma } & ${ }^{*}$ Tidak suka & 3,33 & 6,67 & 6,67 \\
& ${ }^{* *}$ Suka & 96,67 & 93,33 & 93,33 \\
\hline \multirow{2}{*}{ Rasa } & ${ }^{*}$ Tidak suka & 6,67 & 3,33 & 10 \\
& ${ }^{* *}$ Suka & 93,33 & 96,67 & 90 \\
\hline \multirow{2}{*}{ Warna } & ${ }^{*}$ Tidak suka & 3,33 & 6,67 & 13,33 \\
& ${ }^{* *}$ Suka & 96,67 & 93,33 & 86,67 \\
\hline
\end{tabular}

Keterangan:
* Skor hedonik tidak suka : 1 = sangat tidak suka, $2=$ tidak suka, 3 = agak
tidak suka
* *Skor hedonik suka : 4 = agak suka, $5=$ suka, $6=$ sangat suka
Sumber : Data Uji Hedonik, 2018

Berdasarkan penilaian uji daya terima dari 30 panelis wanita hamil pada Tabel 1, didapatkan nilai $p$ pada parameter aroma dan rasa dari formulasi $\mathrm{A} 1, \mathrm{~A} 2$ dan $\mathrm{A} 3$ memiliki nilai $p>0,05$, sehingga dapat disimpulkan tidak ada pengaruh penambahan kacang merah terhadap daya terima pada parameter aroma dan rasa. Sedangkan pada parameter warna didapatkan nilai $p<0,05$, sehingga dapat disimpulkan ada pengaruh penambahan kacang merah terhadap parameter warna. Dapat dilihat dari Tabel 2 menunjukkan bahwa 96,67\% yang artinya 29 dari 30 panelis menyukai warna biskuit kacang merah $\mathrm{A} 1$, serta $13,33 \%$ yang artinya 4 dari 30 panelis tidak menyukai warna biskuit kacang merah A3.

Tabel. 2 Persentase Panelis Terhadap Daya Terima Biskuit Kacang Merah

\begin{tabular}{ccccc}
\hline \multirow{2}{*}{ Kategori } & \multirow{2}{*}{ Skor } & \multicolumn{3}{c}{ Sampel } \\
\cline { 3 - 5 } Aroma & Tidak suka* & 3,33 & A2 $(\%)$ & A3 $(\%)$ \\
& Suka* & 96,67 & 6,67 & 6,67 \\
& Tidak suka* & 6,67 & 3,33 & 93,33 \\
\hline \multirow{2}{*}{ Wasa } & Suka* $^{*}$ Warna & 93,33 & 96,67 & 10 \\
& Tidak suka* & 3,33 & 6,67 & 13,33 \\
& Suka* & 96,67 & 93,33 & 86,67 \\
\hline
\end{tabular}

Keterangan : Skor diatas menunjukkan persentase kesukaan panelis terhadap masing-masing parameter sampel 


\section{Kandungan Zat Besi (Fe)}

Tabel. 3 Kandungan Zat Besi Biskuit Kacang Merah

\begin{tabular}{ccc}
\hline Kode sampel & Zat besi $(\mathrm{mg} / \mathrm{Kg})$ & $p^{\mathrm{a}}$ \\
\hline A1 & 0,05 & 0,06 \\
A2 & 0,05 & 0,368 \\
A3 & \\
Keterangan: & \\
-Nilai p> 0,05 menunjukkan tidak ada perbedaan \\
yang signifikan \\
-Uji yang digunakan Kruskal Wallis Test \\
\multicolumn{3}{c}{ Sumber : Kruskal Wallis }
\end{tabular}

Berdasarkan penilaian uji kandungan zat besi (Fe) pada Tabel 3 menunjukkan nilai $p>0,05$, sehingga dapat disimpulkan tidak ada pengaruh penambahan kacang merah terhadap kandungan zat besi $(\mathrm{Fe})$ $(p=0,368)$.

\section{Kadar Air}

Tabel. 4 Kadar Air Biskuit Kacang Merah

\begin{tabular}{ccccc}
\hline Variabel & A1 & A2 & A3 & $p^{\text {a }}$ \\
\hline $\begin{array}{c}\text { Kadar Air } \\
(\%)\end{array}$ & $2,46^{\mathrm{a}}$ & $3,16^{\mathrm{b}}$ & $5,49^{\mathrm{c}}$ & 0,000 \\
\hline
\end{tabular}

Keterangan:

-Notasi huruf tidak sama ada beda yang signifikan

-Data ini diolah menggunakan metode ANOVA

-Nilai $p<0,05$ menunjukkan data ada beda yang signifikan

Berdasarkan penilaian uji kadar air pada Tabel 4 menunjukkan nilai $p<0,05$, sehingga dapat disimpulkan ada pengaruh penambahan kacang merah terhadap kadar air $(p=0,001)$

\section{PEMBAHASAN}

\section{Daya Terima}

\section{a. Parameter Aroma}

Pada parameter aroma $p=4,90$ $(p>0,05)$, pada Tabel 1, menunjukkan hasil rerata skor uji indrawi terhadap parameter aroma sebesar 4,90 pada A1, 4,67 pada A2 dan 4,67 pada A3, namun dapat dilihat dari persentase panelis rata-rata menyukai biskuit kacang merah baik A1, A2 dan A3. Hasil penelitian sebelumnya tentang pembuatan butter cookies tepung kacang merah yang dilakukan oleh Pratiningrum (2015), menunjukkan aroma paling disukai pada penambahan tepung kacang merah terendah yaitu $60 \% .{ }^{9}$ Hal ini disebabkan semakin banyak tepung kacang merah yang ditambahkan maka semakin langu bau yang dihasilkan pada produk pangan butter cookies. ${ }^{9}$ Bau langu yang dihasilkan kacang merah disebabkan karena kandungan enzim lipoksigenase yang terkandung pada kacang merah yang aktif pada proses pengolahan. ${ }^{10}$ Namun pada penelitian ini biskuit kacang merah yang dihasilkan tidak memiliki bau langu seperti pada penelitian sebelumnya.

\section{b. Parameter Rasa}

Pada parameter rasa $p=0,237$ $(p>0,05)$, pada Tabel 1 hasil rerata skor untuk parameter rasa biskuit kacang merah yaitu 5,00 pada $A 1,5,03$ pada $A 2$ dan 4,63 pada A3. Berdasarkan penelitian sebelumnya tentang butter cookies kacang merah yang dilakukan oleh Pratiningrum (2015), terhadap parameter rasa yang paling disukai yaitu dengan penambahan paling sedikit tepung kacang merah yaitu $60 \% .{ }^{9}$ Karena semakin banyak tepung kacang merah yang ditambahkan maka semakin mengurangi tingkat kemanisan, hal ini disebabkan kacang merah cenderung memiliki rasa yang hambar sehingga meningkatkan rasa gurih pada butter cookies. ${ }^{9}$ Sedangkan pada penelitian ini rasa 
yang dihasilkan dari biskuit kacang merah yaitu sedikit manis dan dominan gurih, semakin banyak penambahan kacang merah maka rasa yang dihasilkan semakin gurih dan rasa manis semakin samar. Sebaliknya semakin sedikit penambahan kacang merah maka rasa yang dihasilkan semakin manis.

\section{c. Parameter Warna}

Pada parameter warna $p=0,028$ $(p=<0,05)$ yang berarti ada pengaruh penambahan kacang merah terhadap daya terima biskuit kacang merah. Berdasarkan uji lanjutan diketahui bahwa parameter warna biskuit kacang merah formulasi A1 berbeda dengan formulasi A2 dan A3, sedangkan A2 tidak berbeda dengan A3 yang dapat dilihat dari notasi huruf yang sama pada Tabel 1. Hasil rerata skor uji indrawi pada parameter warna sebesar 5,27 pada A1, 4,80 pada A2 dan 4,67 pada A3.

Dari hasil persentase penilaian biskuit kacang merah pada Tabel 2 pada kategori warna menunjukkan persentase tertinggi sebesar 96,67\% dengan kriteria suka pada formulasi A1 (perbandingan tepung terigu:tepung kacang merah 80\%:20\%), yang artinya 29 dari 30 panelis menyukai warna biskuit kacang merah A1. Sedangkan untuk skor tidak disukai tertinggi yaitu sebesar 13,33\% pada formulasi A3 (perbandingan tepung terigu : tepung kacang merah 20\%:80\%), yang artinya 4 dari 30 panelis tidak menyukasi warna biskuit kacang merah A3.

Menurut penelitian yang dilakukan oleh Pratiningrum (2015) warna butter cookies tepung kacang merah substitusi tepung terigu paling disukai dengan penambahan tepung kacang merah $70 \%$, dengan warna kuning keemasan yang dipengaruhi oleh jumlah tepung kacang merah yang ditambahkan. ${ }^{9}$ Semakin banyak tepung kacang merah yang ditambahkan maka warna butter cookies semakin gelap. Pada penelitian ini biskuit kacang merah yang dihasilkan memiliki warna kuning keemasan yang dipengaruhi oleh kandungan kacang merah, semakin tinggi kandungan kacang merah maka semakin pekat warna yang dihasilkan.
Berdasarkan uji daya terima dengan para meter aroma, rasa dan warna biskuit yang paling disukai panelis yaitu pada biskuit dengan penambahan tepung kacang merah 10\%. Hal ini disebabkan karena cita rasa biskuit yang ditambahkan kacang merah terasa pahit. ${ }^{11}$ Sedangkan pada penelitian ini formulasi biskuit kacang merah memiliki rerata persentase disukai baik dari segi aroma, rasa dan warna yang dapat dilihat pada Tabel 2. Penambahan kacang merah dengan formulasi berbeda terhadap biskuit tidak berpengaruh pada aroma dan rasa namun berpengaruh pada warna biskuit kacang merah.

\section{Kandungan Zat Besi}

Perkiraan kandungan zat besi (Fe) biskuit kacang merah berdasarkan perhitungan komposisi bahan adalah 3,9mg-7,8mg per $100 \mathrm{~g}$ biskuit. Namun setelah diuji menggunakan metode AAS hasil kadar zat besi (Fe) yang didapat adalah 0,05mg/Kg (Tabel 3). Hal ini menunjukkan penurunan kadar zat besi sebesar 98,7\% - 99,9\%. Penurunan tersebut disebabkan oleh perlakuan pada pembuatan tepung kacang merah yang kurang tepat. Proses perendaman dan perebusan pada kacang merah selain dapat menghilangkan asam fitat namun juga dapat menghilangkan kandungan zat besi. ${ }^{12}$ Selain dari proses perendaman dan perebusan yang dapat mengurangi kandungan zat besi, pada proses pengupasan kulit ari kacang merah dapat mengurangi kandungan gizi yang banyak terkandung didalamnya. Pembuatan tepung kacang merah lebih baik untuk tidak mengupas kulit arinya, hal ini disebabkan karena sebagian besar zat gizi terkandung dalam kulit kacang merah. ${ }^{9}$ Zat besi selain didapatkan dari sumber kacang merah dapat juga didukung dari penambahan bahan lain seperti tepung terigu yang sebelumnya sudah mendapatkan fortifikasi zat besi, sebesar $20 \%$ pada biskuit dan telur. Meski sudah menggunakan bahan tambahan yang telah melalui fortifikasi zat besi (Fe), hasil yang didapatkan masih kurang dari kebutuhan asupan zat besi (Fe) bagi ibu hamil.

Hasil penelitian sebelumnya menunjukan adanya peningkatan kandungan zat besi pada biskuit, dengan 
kandungan zat besi (Fe) tertinggi pada formulasi tepung biji nangka, tepung kacang merah dan tepung pisang $\mathrm{A} 3=4: 4: 7$ yaitu 2,15mg per $100 \mathrm{~g}$ biskuit. ${ }^{13}$ Hasil penelitian sebelumnya menunjukkan kandungan zat besi (Fe) lebih tinggi dari kandungan zat besi $(\mathrm{Fe})$ biskuit kacang merah yang dibuat oleh peneliti. Hal ini disebabkan pada penelitian sebelumnya menambahkan berbagai macam tepung lain yang mendukung peningkatan zat besi, sehingga perlu perbaikan formulasi untuk penelitian ini.

Kebutuhan zat besi (Fe) pada wanita hamil sebesar $39 \mathrm{mg}$ perhari (26mg dari kebutuhan wanita usia 13-49 tahun dan ditambah $13 \mathrm{mg}$ pada masa kehamilan). ${ }^{14}$ Pemerintah sendiri memiliki program pemberian tablet tambah darah (TTD) selama 9 bulan kehamilan. TTD yang diberikan mengandung $60 \mathrm{mg}$ zat besi (Fe). Banyak dari ibu hamil yang tidak mengkonsumsi TTD secara rutin dikarenakan rasa mual yang ditimbulkan oleh TTD yang dikonsumsi berbau besi. Kebanyakan wanita hamil juga mengalami penurunan asupan makanan yang disebabkan rasa mual. Kandungan zat besi (Fe) pada biskuit kacang masih jauh lebih sedikit dari kandung TTD yang diberikan pemerintah, namun diharapkan biskuit kacang merah ini menjadi alternatif makanan tambahan bagi wanita hamil yang sama sekali tidak bisa mengkonsumsi TTD.

Selain dari TTD, zat besi (Fe) dapat diperoleh dari konsumsi harian, dengan perhitungan makan 3 kali sehari (1000$2500 \mathrm{kcal}$ ) akan menghasilkan sekitar 10$15 \mathrm{mg}$ zat besi (Fe) perhari. ${ }^{15}$ Dengan mengkonsumsi biskuit sebanyak $1 \mathrm{~kg}$ hanya dapat memenuhi kebutuhan 0,05-0,06 $\mathrm{mg} / \mathrm{Kg} \mathrm{Fe}$ per hari saja. Namun biskuit kacang merah tetap dapat dijadikan makanan alternatif bagi wanita hamil yang sama sekali tidak bisa mengkonsumsi makanan karena mual muntah. Dari $100 \mathrm{~g}$ biskuit menyumbang energi 721,18 kcal, protein 28,98 g, lemak 49,62 g dan karbohidrat 122,42 g. Energi yang dihasilkan sudah memenuhi syarat SNI biskuit per 100 g yaitu minimum 400 kcal. ${ }^{16}$

\section{Kadar Air}

Dari Tabel 4 diatas menunjukkan bahwa $p<0,05$ ada perbedaan yang signifikan yang berarti ada pengaruh terhadap kadar air biskuit dengan penambahan kacang merah 20\%, 50\% dan $80 \%$, dilihat dari notasi huruf yang berbeda menunjukkan perbedaan antara A1, A2 dan A3. Hasil uji kadar air yang dilakukan pada biskuit kacang merah menyatakan bahwa biskuit A1 dan A2 memenuhi kriteria SNI yaitu dibawah 5\%, sedangkan untuk A3 tidak memenuhi kriteria SNI.

Kacang merah merupakan jenis kacang yang memiliki protein yang tinggi, protein pada kacang merah dapat mengikat air. Sehingga semakin banyak tepung kacang merah yang ditambahkan kedalam adonan biskuit maka semakit tinggi kadar air pada biskuit. ${ }^{17}$ Pada penelitian Desrosier (2008) menyatakan bahwa besarnya kandungan air pada produk biskuit dapat mempengaruhi cita rasa maupun tekstur pada biskuit.18 Kadar air dapat mempengaruhi daya terima ibu hamil terhadap biskuit, karena kacang merah lebih banyak memiliki aroma yang pekat berbau kacang merah, warna yang kurang menarik, mengurangi rasa renyah biskuit.

$$
\text { Menurut Hidayati }
$$
menyebutkan bahwa keluhan yang terjadi pada ibu hamil yaitu produksi air liur yang berlebihan biasanya juga mengalami gejala mual dan muntah (Morning Sickness). ${ }^{19}$ Kondisi ini saling berhubungan karena menelan air liur dapat memicu mual muntah. Sehingga dibutuhkan makanan yang tidak terlalu banyak mengandung air agar tidak menambah jumlah air liur yang mengakibatkan mual, seperti biskuit kacang merah kering yang bermanfaat untuk mengurangi rasa mual akibat banyaknya produksi air liur saat masa kehamilan.

\section{SIMPULAN}

Penambahan kacang merah pada biskuit dengan formulasi yang digunakan pada penelitian ini tidak menunjukkan adanya pengaruh terhadap daya terima pada parameter aroma dan rasa, namun memberikan pengaruh terhadar daya terima pada parameter warna. Sedangkan kandungan zat besi pada biskuit dengan penambahan kacang merah belum 
meningkat secara signifikan.

\section{DAFTAR PUSTAKA}

1. Riset Kesehatan Dasar (Riskesdas). 2013. Badan Penelitian dan Pengembangan Kesehatan Kementerian Kesehatan RI. Jakarta: 2013. Diakses pada tanggal 20 Februari 2018

2. Kementerian Kesehatan RI. 2015. Profil Kesehatan Indonesia Tahun 2014. Jakarta: Kementerian Kesehatan RI. Diakses pada tanggal 16 Maret 2018

3. Krisnawati., Desi, Ari, Madi, Yanti \& Apri, Sulistianingsih. (2015). Faktor Faktor Terjadinya Anemia Pada Ibu Primigravida Di Wilayah Kerja Puskesmas Tahun 2015. STIKES Peringsewu Lampung.

4. Suparmi., Susilowati, A \& Saptarini, I. 2015. Faktor Faktor Yang Berhubungan Dengan Konsumsi Tablet Besi Pada Ibu Hamil Di Kelurahan Kebon Kelapa, Bogor

5. Petry, Nicolai., Erick, Boy., James P.W and Richard F.H. 2015. The Potential of the Common Bean (Phaseolus vulgaris) as a Vehicle for Iron

6. Badan Pusat Statistik. 2011. Produksi Sayuran di Indonesia. Diakses pada tanggal 10 Februari 2018.

7. Rebellato, Paula, Ana., Beatriz, C.P., Juliana P.P and Juliana, Azevedo, Lima, Pallone. 2015. Iron in fortified biscuits: $A$ simple method for its quantification,bioaccessibility study and physicochemical quality Biofortification

8. Saksono, H. 2012. Pasar Biskuit Diproyeksi Tumbuh 8\% Didorong Konsumsi. Diakses dari: www.indonesiafinancetoday.com. Diakses pada tanggal 30 Januari 2018

9. Pratiningrum,W. 2015. Eksperimen Pembuatan Butter Cookies Tepung Kacang Merah Substitusi Tepung Terigu. [Skripsi] Sarjana Jurusan Kesejahteraan Keluarga Tata Boga, Fakultas Teknik Universitas Negri Semarang.

10. Agustian, Citra, Friska., Yovita, $P, S$ \& Almira, Sitasari. 2016. Formulasi Dan Karakterisasi Mi Bebas Gluten Tinggi Protein Berbahan Pati Sagu Yang Disubstitusi Tepung Kacang-Kacangan. J.Gizi Pangan.
11. Fatimah, P.S., Nasution \& Aritonang. 2015. Uji Daya Terima Dan Nilai Gizi Biskuit Yang Dimodifikasi Dengan Tepung Kacang Merah. [Artikel] Departemen Gizi Kesehatan Masyarakat Fakultas Kesehatan Masyarakat USU. Medan

12. Mohamed, R., E.A., Abou-Arab, A.Y., Gibriel, N.M.H., Rasmy, F.M \& Abu Salem. 2011. Effect of Legume Processing Treatments Individually or In Combination on Their Phytic Acid Content. African Journal of Food Science and Technology (ISSN:2141-5455) Vol. 2(2) pp. 036-046, Juli, 2018.

13. Chairannisa, Citra., Albiner Siagian \& Ernawati Nasution. 2015. Daya Terima Biskuit Dengan Modifikasi Tepung Biji Nangka, Tepung Kacang Merah Dan Tepung Pisang Serta Kontribusinya Terhadap Kecukupan Energi, Protein Dan Zat Besi Remaja.

14. Kementrian Kesehatan RI. 2014. Pedoman Gizi Seimbang: Jakarta. Kementrian kesehatan RI 2014. Pada tanggal 18 Maret 2018

15. Departemen Kesehatan R.I. 2001. Program Penanggulangan Anemia Gizi pada Wanita Usia Subur (WUS); (Safe Motherhood Project: A Partnership and Family Approach). Direktorat Gizi Masyarakat. Jakarta: Direktorat Jenderal Bina Kesehatan Masyarakat Depkes

16. SNI. 1992. Syarat Mutu Biskuit. Diakses dari www.repository.usu.ac.id. Diakses pada 1 Agustus 2018

17. Nurlita., Hermanto \& Nur Asyik. 2017. The effect of the addition of red bean flour (Phaseolus vulgaris $L$ ) and yellow gourd flour (Cucurbita moschata) on organoleptic and nutritional value of biscuit). J. Sains Dan Teknologi Pangan Vol. 2, No.3, P. 562-574, Th. 2017

18. Desrosier. 2008. Influence of Traditional Processing Methods On The Nutrition

19. Hidayati, R. 2009. Asuhan Keperawatan pada Kehamilan Fisiologis dan Patologis. Jakarta: Salemba Medika. 